\title{
Chemical composition of fresh snow from Glaciar Marinelli, Tierra del Fuego, Chile
}

\author{
B. GRIGHOLM, ${ }^{1}$ P.A. MAYEWSKI, ${ }^{1}$ A.V. KURBATOV, ${ }^{1}$ Gino CASASSA, ${ }^{2}$ \\ A. CONTRERAS STAEDING, ${ }^{3}$ M. HANDLEY, ${ }^{1}$ S.B. SNEED, ${ }^{1}$ D.S. INTRONE ${ }^{1}$ \\ ${ }^{1}$ Climate Change Institute, University of Maine, 133 Sawyer Environmental Research Center, Orono, Maine 04469, USA \\ E-mail: bjorn.grigholm@maine.edu \\ ${ }^{2}$ Centro de Estudios Cientificos, Av. Arturo Prat 514, Casilla 1469, Valdivia, Chile \\ ${ }^{3}$ DAP, O'Higgins 891, Punta Arenas, Chile
}

\begin{abstract}
A fresh-snow sampling campaign was conducted during the late austral summer of 2006 in the accumulation zone of Glaciar Marinelli, located in the Cordillera Darwin, Tierra del Fuego, Chile. Snow samples were analyzed for stable isotopes $\left(\delta^{18} \mathrm{O}\right)$, major soluble ions $\left(\mathrm{Na}^{+}, \mathrm{K}^{+}, \mathrm{Ca}^{2+}, \mathrm{Mg}^{2+}, \mathrm{Cl}^{-}\right.$, $\mathrm{NO}_{3}{ }^{-}, \mathrm{SO}_{4}{ }^{2-}, \mathrm{MS}^{-}$) and major and trace elements ( $\mathrm{Na}, \mathrm{Mg}, \mathrm{Al}, \mathrm{Fe}, \mathrm{Ca}, \mathrm{Sr}, \mathrm{Cd}, \mathrm{Cs}, \mathrm{Ba}, \mathrm{La}, \mathrm{Ce}, \mathrm{Pr}, \mathrm{Dy}, \mathrm{Ho}$, $\mathrm{Er}, \mathrm{Bi}, \mathrm{U}, \mathrm{As}, \mathrm{Ti}, \mathrm{V}, \mathrm{Cr}, \mathrm{Mn})$. The dominance of marine chemistry resembles that in studies from Patagonian glaciers. Snow chemistry was dominantly loaded by marine species $\left(\mathrm{Cl}^{-}, \mathrm{Na}^{+}\right.$and ssSO $\left.{ }_{4}{ }^{2-}\right)$, while contributions of crustal species (e.g. Al and Fe) were very low. Empirical orthogonal function analysis suggests two possible dust sources, one represented by Al and Fe and the other by La, Ce and Pr. Enrichment-factor calculations suggest the majority of elements are within average upper-crustal ratios, but major enrichments of $\mathrm{Bi}$ and $\mathrm{Cd}$ (hundreds of times) suggest possible anthropogenic sources. Linear correlation of $\delta^{18} \mathrm{O}$ and barometric pressure $(r=0.60, p<0.007)$ suggests a potential 'amount effect' relationship between depleted $\delta^{18} \mathrm{O}$ ratios and stronger storm conditions (e.g. greater precipitation). The snow-chemistry records from Glaciar Marinelli are the first measured in Tierra del Fuego, the southernmost glaciated region outside Antarctica.
\end{abstract}

\section{INTRODUCTION}

Snow has the unique characteristic of filtering and collecting aerosols from the atmosphere and holds the potential to record the chemical composition changes of the atmosphere over time. Therefore, study of the chemical compositions of fresh-snow samples from glaciers can reveal information on atmospheric components, sources, transport pathways and background atmospheric aerosol concentrations (Mayewski and others, 1983; Shaw, 1988). In addition, the understanding of present relationships of aerosols and moisture sources is crucial in interpreting temporally longer glaciochemical records such as ice cores, which are proven to be an excellent tool to investigate the atmospheric composition of the past (Mayewski and others, 1984; Legrand and Mayewski, 1997). Glaciochemical studies in southern South America have been limited to a few studies in Patagonia (Yamada, 1987; Aristarain and Delmas, 1993; Shiraiwa and others, 2002; Schwikowski and others, 2006; Vimeux and others, 2008) and no data are available for the Cordillera Darwin, the southernmost mountain range in South America and the glaciated region closest to Antarctica. As with most Andean and Patagonian glaciers, Tierra del Fuego is remote from industrial centers; however, local cities/towns, logging activities and marine traffic may expose glaciers to measurable amounts of pollutants. We present results of fresh-snow concentrations of stable isotopes, major soluble ions and major and trace elements during a 17 day sampling campaign in the late austral summer (February-March) of 2006. The purpose of this study was to retrieve chemical concentrations in fresh snow and to evaluate inter-species relationships (e.g. marine, crustal and possible anthropogenic influences) along with meteorological mechanisms. Statistical analysis of the chemistry time series and on-site barometric pressure measurements, examination of US National Oceanic and Atmospheric Administration (NOAA) Hysplit 7 day back trajectories, and preliminary regional glaciochemical record comparisons are presented.

\section{STUDY AREA}

The research site was located on Glaciar Marinelli (54 $38.878^{\prime} \mathrm{S}, 69^{\circ} 43.206^{\prime} \mathrm{W} ; 1823 \mathrm{ma.s.I.}$; $142 \mathrm{~km}^{2}$ ) in the Cordillera Darwin in the southwestern region of Tierra Del Fuego, Chile (Fig. 1). Glaciar Marinelli is the largest glacier in the Cordillera Darwin and is reported to have receded $5 \mathrm{~km}$ between 1960 and 1993 (Holmlund and Fuenzalida, 1995). Recent observations from the summit of Glaciar Marinelli during the snow-sampling campaign suggest that the recession is progressing. The Cordillera Darwin is close to large moisture sources, the two largest being the Pacific Ocean $(\sim 100 \mathrm{~km}$ to the west) and the Atlantic Ocean ( $\sim 150 \mathrm{~km}$ to the east).

As a result of limited land masses in the southern Pacific and a strong temperature gradient between the Antarctic continent and the Southern Hemispheric subtropics, the Cordillera Darwin is dominated by strong year-round westerlies (Miller, 1976). Evaluation of the Tierra del Fuego region with US National Centers for Environmental Prediction (NCEP)/US National Center for Atmospheric Research (NCAR) reanalysis (Kalnay and others, 1996) shows the surface-level scalar wind velocities reaching maximums in the austral spring (September-November) and austral summer (December-February). Lowest wind velocities are experienced during the austral winter (June-August). Mean annual scalar wind velocities are $\sim 8 \mathrm{~m} \mathrm{~s}^{-1}$. Monthly NCEP/ NCAR surface precipitation data (covering 1960-2000) 


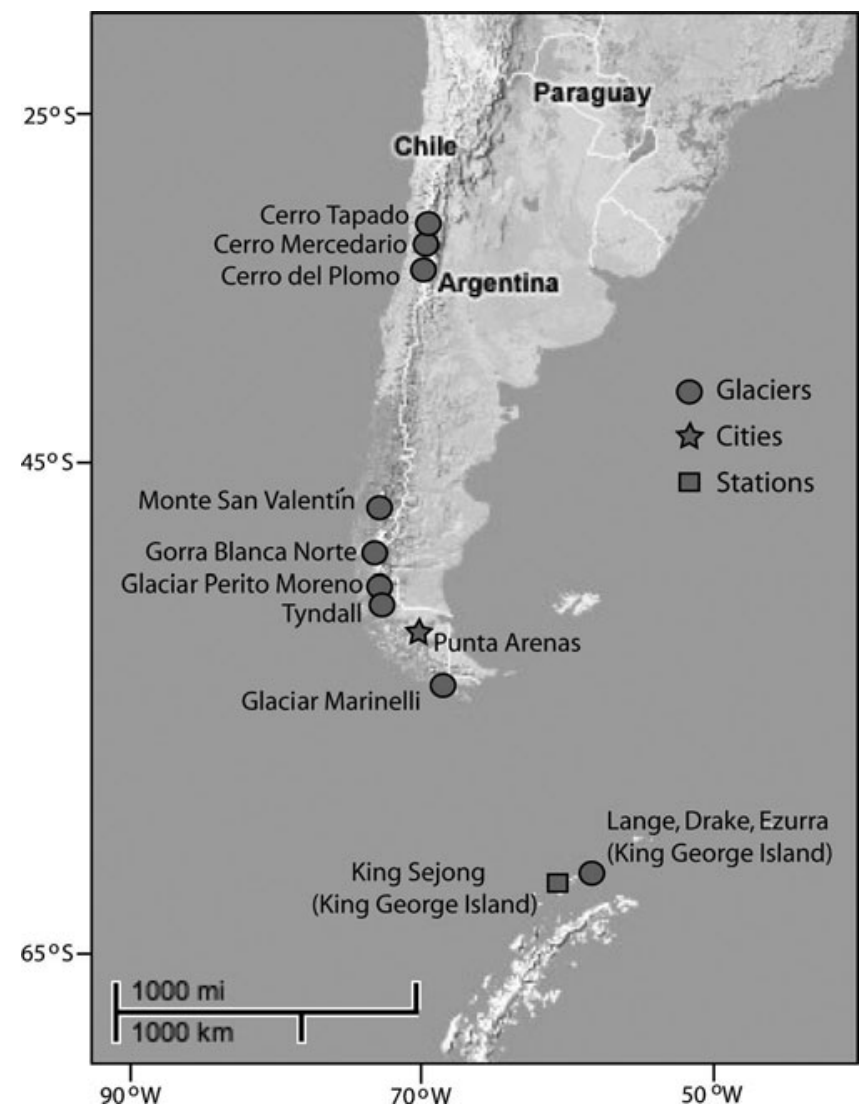

Fig. 1. Location map (Google Maps image). Glaciers and stations labeled contain available snow- and ice-chemistry data (see references in text).

show that Tierra del Fuego receives steady precipitation throughout the year, but the greatest precipitation occurs during spring and winter.

\section{METHODOLOGY \\ Snow sampling}

The fresh surface snow study was conducted in the accumulation zone of Glaciar Marinelli from 24 February to 12 March 2006. Samples were collected in the morning, at midday and in the evening, upwind of camp on a gently sloped glacier section away from valley walls and crevasse fields. Sample-collection times are presented in Table 1. Snowfall persisted almost throughout the sampling campaign. Each sample was collected between ( 6 samples) or during (20 samples) snowfall events. Samples were collected using a plastic spade pre-cleaned with deionized (DI) water $(>18.2 \mathrm{M} \Omega$ ) by a researcher wearing a non-particulating suit, face mask and wrist-length polypropylene (PP) gloves. To assure that each sample represented the most recent snowfall, only the top centimeter of surface snow was collected and placed into Teflon bags. The Teflon bags were subsequently stored inside Whirl-Pak ${ }^{\circledR}$ bags. Twenty-six snow samples were collected and poured into high-density polyethylene (HDPE) vials for analysis of stable-isotope ratios $\left(\delta^{18} \mathrm{O}\right)$ and into pre-cleaned (with $\mathrm{DI}$ water) polypropylene (PP) vials for analysis of soluble ion concentrations $\mathrm{Na}^{+}, \mathrm{K}^{+}, \mathrm{Ca}^{2+}, \mathrm{Mg}^{2+}, \mathrm{Cl}^{-}, \mathrm{NO}_{3}{ }^{-}, \mathrm{SO}_{4}{ }^{2-}, \mathrm{MS}^{-}$ (methane sulfonate)). Major- and trace-element $(\mathrm{Na}, \mathrm{Mg}, \mathrm{Al}$, $\mathrm{Fe}, \mathrm{Ca}, \mathrm{Sr}, \mathrm{Cd}, \mathrm{Cs}, \mathrm{Ba}, \mathrm{La}, \mathrm{Ce}, \mathrm{Pr}, \mathrm{Dy}, \mathrm{Ho}, \mathrm{Er}, \mathrm{Bi}, \mathrm{U}, \mathrm{Ti}, \mathrm{V}, \mathrm{Cr}$, $\mathrm{Mn})$ vial-cleaning procedures are presented by Osterberg
Table 1. Sample-collection times and co-registered temperature and pressure measurements

\begin{tabular}{|c|c|c|c|c|}
\hline Sample & Date & Time & $\begin{array}{c}\text { Temp. } \\
{ }^{\circ} \mathrm{C}\end{array}$ & $\begin{array}{c}\text { Pressure } \\
\mathrm{hPa}\end{array}$ \\
\hline 1 & 24 Feb 2006 & $16: 55$ & 1.17 & 805.0 \\
\hline 2 & 24 Feb 2006 & $20: 41$ & -0.11 & 805.0 \\
\hline 3 & 25 Feb 2006 & $08: 30$ & -5.61 & 797.2 \\
\hline 4 & 25 Feb 2006 & $16: 57$ & 0.06 & 795.7 \\
\hline 5 & 25 Feb 2006 & 19:30 & -0.44 & 795.4 \\
\hline 6 & 26 Feb 2006 & 09:30 & -6.61 & 789.0 \\
\hline 7 & 26 Feb 2006 & 19:14 & -0.06 & 786.1 \\
\hline 8 & 27 Feb 2006 & 10:02 & -4.22 & 782.0 \\
\hline 9 & 27 Feb 2006 & 19:04 & -3.22 & 786.1 \\
\hline 10 & 28 Feb 2006 & $16: 30$ & 0.22 & 797.0 \\
\hline 11 & 2 Mar 2006 & $17: 22$ & -1.39 & 798.0 \\
\hline 12 & 2 Mar 2006 & $21: 30$ & no data & 798.0 \\
\hline 13 & 3 Mar 2006 & $11: 15$ & 0.50 & 795.0 \\
\hline 14 & 3 Mar 2006 & 19:00 & 0.50 & 796.0 \\
\hline 15 & 5 Mar 2006 & $12: 00$ & 0.00 & 782.0 \\
\hline 16 & 5 Mar 2006 & 18:00 & -1.94 & 786.0 \\
\hline 17 & 6 Mar 2006 & $10: 20$ & -1.06 & 783.5 \\
\hline 18 & 6 Mar 2006 & $20: 30$ & -0.56 & 776.0 \\
\hline 19 & 7 Mar 2006 & $11: 45$ & 0.00 & 776.0 \\
\hline 20 & 7 Mar 2006 & $17: 50$ & 0.50 & 778.6 \\
\hline 22 & 8 Mar 2006 & $17: 30$ & -0.83 & 785.0 \\
\hline 23 & 9 Mar 2006 & $17: 45$ & -0.78 & 799.0 \\
\hline 24 & 10 Mar 2006 & $12: 00$ & 0.17 & 793.0 \\
\hline 25 & 10 Mar 2006 & 20:30 & 0.17 & 790.0 \\
\hline 26 & 11 Mar 2006 & $17: 00$ & -0.56 & 786.0 \\
\hline 27 & 12 Mar 2006 & 08:00 & 0.00 & 791.0 \\
\hline
\end{tabular}

and others (2006). The samples were analyzed for stable isotopes, major soluble ions and trace elements at the Climate Change Institute, University of Maine, using a Micromass Isoprime ion chromatograph, a VG/Micromass SIRA, a Dionex DX-500 ion chromatograph and a ThermoFinnigan Element 2 inductively coupled plasma sector field mass spectrometer (ICP-SMS) respectively. The ICP-SMS is coupled with a microflow nebulizer/desolvation introduction system to reduce potential spectroscopic interferences (Field and Sherrell, 2003; Gabrielli and others, 2006). ICPSMS samples were acidified to $1 \%$ with double-distilled $\mathrm{HNO}_{3}$ under a class 100 High Efficiency Particle Air (HEPA) clean bench and allowed to react with the acid for approximately 1 week before being frozen. Samples were melted at room temperature approximately 24 hours prior to analysis. A summary of Teflon bag blank values and calculated detection limits $(3 \sigma)$ is presented in Table 2. All major soluble-ion and element-sample concentrations were more than three times Teflon bag detection limits (TBDL), except for the minimum value of $\mathrm{Cr}$ and $\mathrm{Pr}$ in two of the samples. The minimum value of $\mathrm{Cr}$ was less than TBDL, so the detection limit was used for statistical calculations. However, the minimum value of $\operatorname{Pr}$ was approximately three times the TBDL and therefore was left unchanged.

\section{Observed meteorology}

During the sampling sessions, temperature and barometric pressure were recorded using a Kestrel ${ }^{\mathbb{B}} 2500$ Pocket Wind Meter (Table 1). Daily measurements of temperature, observations of mixed rain-snow precipitation, and melt layers detected in snow pits suggested that temperatures above 
Table 2. Statistical summary of stable isotopes (\%o Standard Mean Ocean Water (SMOW)), major soluble ion $\left(\mu \mathrm{L}^{-1}\right)$ and major trace element (ng L ${ }^{-1}$ ) concentrations determined at Glaciar Marinelli (24 February-12 March 2006)

\begin{tabular}{|c|c|c|c|c|c|c|c|c|}
\hline Analyte & Mean & Median & $\mathrm{SD}^{*}$ & Min. & Max. & TB blank ${ }^{\dagger}$ & $\mathrm{TB} \mathrm{DL}^{\star}$ & $\mathrm{IDL}^{\S}$ \\
\hline \multicolumn{9}{|c|}{ Stable isotopes } \\
\hline$\delta^{18} \mathrm{O}^{\pi}$ & -10.19 & -10.23 & 2.23 & -13.24 & -6.99 & - & - & - \\
\hline \multicolumn{9}{|c|}{ Major soluble ions } \\
\hline $\mathrm{Na}^{+}$ & 187.39 & 141.38 & 168.97 & 21.68 & 700.97 & 0.39 & 1.18 & 0.31 \\
\hline $\mathrm{K}^{+}$ & 19.63 & 18.14 & 14.84 & 3.05 & 75.26 & 1.36 & 1.31 & 0.12 \\
\hline $\mathrm{Mg}^{2+}$ & 20.94 & 15.94 & 17.87 & 3.32 & 75.52 & 0.18 & 0.54 & 0.06 \\
\hline $\mathrm{Ca}^{2+}$ & 14.28 & 11.25 & 9.12 & 4.26 & 36.13 & 0.54 & 1.62 & 0.32 \\
\hline MS & 13.01 & 10.47 & 8.27 & 2.55 & 34.67 & $<\mathrm{IDL}$ & $<\mathrm{IDL}$ & 0.43 \\
\hline $\mathrm{Cl}^{-}$ & 340.40 & 253.09 & 310.56 & 37.26 & 1297.05 & 1.01 & 1.13 & 0.26 \\
\hline $\mathrm{NO}_{3}^{-}$ & 18.53 & 11.15 & 17.49 & 3.32 & 75.02 & $<\mathrm{IDL}$ & $<\mathrm{IDL}$ & 0.24 \\
\hline $\mathrm{SO}_{4}{ }^{2-}$ & 97.49 & 86.57 & 61.99 & 24.72 & 314.45 & $<\mathrm{IDL}$ & $<\mathrm{IDL}$ & 1.16 \\
\hline \multicolumn{9}{|c|}{ Major and trace elements" } \\
\hline $\mathrm{Sr}$ & 157.4 & 149.9 & 119.3 & 26.2 & 464.4 & 2.0 & 5.5 & 0.3 \\
\hline $\mathrm{Cd}$ & 5.28 & 2.65 & 8.15 & 1.39 & 32.36 & 0.19 & 0.32 & 0.03 \\
\hline Cs & 0.80 & 0.66 & 0.73 & 0.10 & 3.32 & 0.01 & 0.03 & 0.007 \\
\hline $\mathrm{Ba}$ & 91.89 & 79.84 & 63.43 & 26.86 & 311.33 & 5.57 & 9.50 & 0.33 \\
\hline La & 12.77 & 4.15 & 24.61 & 0.75 & 118.52 & 0.03 & 0.15 & 0.01 \\
\hline $\mathrm{Ce}$ & 16.35 & 8.42 & 19.90 & 0.99 & 74.85 & 0.10 & 0.32 & 0.01 \\
\hline $\operatorname{Pr}$ & 2.04 & 0.87 & 3.38 & 0.11 & 15.74 & 0.02 & 0.04 & 0.002 \\
\hline Dy & 0.424 & 0.194 & 0.881 & 0.040 & 4.446 & 0.009 & 0.018 & 0.011 \\
\hline Ho & 0.084 & 0.042 & 0.167 & 0.012 & 0.845 & 0.002 & 0.007 & 0.001 \\
\hline $\mathrm{Er}$ & 0.247 & 0.129 & 0.455 & 0.030 & 2.303 & 0.006 & 0.016 & 0.005 \\
\hline $\mathrm{Bi}$ & 18.2 & 11.4 & 24.1 & 0.3 & 119.5 & 0.0 & 0.1 & 0.03 \\
\hline U & 0.898 & 0.681 & 0.517 & 0.284 & 2.243 & 0.025 & 0.054 & 0.006 \\
\hline $\mathrm{Al}$ & 16289 & 7132 & 35141 & 3100 & 178315 & 117 & 768 & 40 \\
\hline $\mathrm{Ca}$ & 15234 & 11740 & 8528 & 3739 & 32520 & 282 & 1635 & 110 \\
\hline $\mathrm{Ti}$ & 172.0 & 102.0 & 200.7 & 24.9 & 982.0 & 2.6 & 13.6 & 0.7 \\
\hline V & 11.7 & 7.6 & 11.2 & 4.3 & 59.8 & 0.3 & 0.3 & 0.1 \\
\hline $\mathrm{Cr}$ & 121.0 & 73.1 & 106.9 & 7.7 & 418.2 & 6.2 & 7.7 & 0.14 \\
\hline$M n$ & 145.7 & 104.5 & 137.4 & 54.1 & 716.9 & 4.5 & 9.8 & 1 \\
\hline $\mathrm{Fe}$ & 6106 & 3423 & 9731 & 423 & 50064 & 62 & 31 & 10 \\
\hline $\mathrm{Na}$ & 187634 & 151444 & 166902 & 21363 & 704289 & 418 & 1178 & - \\
\hline$M g$ & 25300 & 18809 & 18248 & 6002 & 79367 & 446 & 395 & - \\
\hline
\end{tabular}

Note: Number of $\delta^{18} \mathrm{O}$ samples $=19$; number of ion samples $=23$; number of element samples $=24$.

* Standard deviation of sample data.

${ }^{\dagger}$ Median of ten DI water samples collected from Teflon bags.

*Teflon bag detection limits calculated by $3 \sigma$ of ten DI water samples from Teflon bags.

$\S$ Instrument detection limits calculated by $3 \sigma$ of ten DI water samples for trace elements.

"Standard deviation of known standard (SMOW) is $\pm 0.1 \%$.

IIDL are from Osterberg and others (2006). $\mathrm{Na}$ and Mg were not calculated in this study.

freezing are present during the summer. The on-site mean temperature was $-0.96 \pm 1.95^{\circ} \mathrm{C}$. NCEP/NCAR reanalysis data for the sampling site between 24 February and 13 March 2006 at the $850 \mathrm{hPa}$ level revealed mean air temperature of $0-1{ }^{\circ} \mathrm{C}$. During the 3 week field campaign, heavy snowfall was observed. A $3 \mathrm{~m}$ long accumulation/ velocity stake revealed a $\sim 1.2 \mathrm{~m}$ snow accumulation over a 15 day period. On-site mean barometric pressure was $790.45 \pm 8.17 \mathrm{hPa}$.

\section{RESULTS AND DISCUSSION}

\section{Concentrations and statistical analysis of major soluble ions}

Statistical summaries of soluble ion concentrations are presented in Table 2. The total median concentration load was $5481 \mu \mathrm{g} \mathrm{L}^{-1}$. Based on concentration, major soluble ions can be categorized into two groups: (1) high concentrations: $\mathrm{Cl}^{-}, \mathrm{Na}^{+}$and $\mathrm{SO}_{4}{ }^{2-}$ representing $46.2 \%, 25.8 \%$ and $15.8 \%$ of total ion concentrations respectively; and (2) low concentrations: $\mathrm{K}^{+}, \mathrm{Ca}^{2+}, \mathrm{MS}^{-}, \mathrm{Mg}^{2+}$ and $\mathrm{NO}_{3}{ }^{-}$representing $3.3 \%, 2.9 \%, 2.0 \%, 1.9 \%$ and $2.0 \%$ of total ion concentration respectively. The dominant presence of the major sea-salt components $\mathrm{Cl}^{-}$and $\mathrm{Na}^{+}$reflects the proximity of Glaciar Marinelli to the Pacific Ocean. The mean $\mathrm{Cl}^{-} / \mathrm{Na}^{+}$ ratio was 1.17 , very close to the sea-water ratio of 1.16 .

In order to help determine the sea-salt (ss) and non-seasalt (nss) contributions of the major soluble ion load, nonsea-salt and sea-salt ratios were calculated using

$$
[\mathrm{nss} X]=[X]-k\left[\mathrm{Na}^{+}\right] \text {, }
$$

where $X$ is the soluble ion concentration of snow sample $\left(\mu \mathrm{g} \mathrm{L}^{-1}\right), k$ is $[X] /\left[\mathrm{Na}^{+}{ }_{\text {standard sea water }}\right]$ and nss $X$ is the non-seasalt $X$ concentration of the snow sample $\left(\mu \mathrm{g} \mathrm{L}^{-1}\right)$.

$\mathrm{Na}^{+}$was used as the reference species and is therefore assumed to originate completely from sea water. Sea-water ratios are from Holland (1978). Calculations indicate that $99 \%$ of $\mathrm{Cl}^{-}$and $\mathrm{Mg}^{2+}$ is derived from sea water. This is not surprising given the proximity of the site to the Pacific Ocean. Concentrations of $\mathrm{Ca}^{2+}, \mathrm{K}^{+}$and $\mathrm{SO}_{4}{ }^{2-}$, however, were suggested to have additional nss sources accounting 


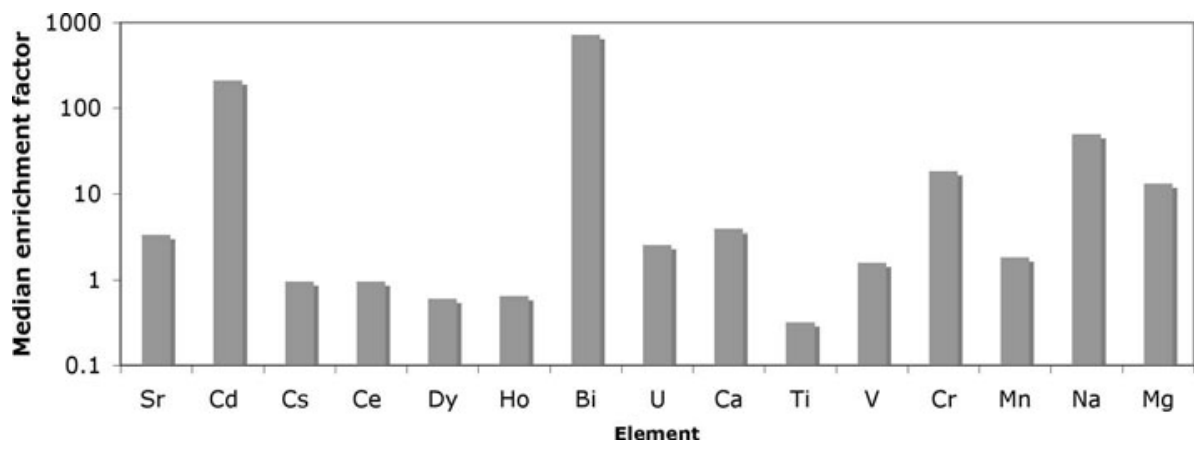

Fig. 2. Median enrichment factors for the measured elements.

for $50 \%, 61 \%$ and $52 \%$ of each ion respectively. $\mathrm{SO}_{4}{ }^{2-}$ represents $15.8 \%$ of total ion concentrations; this high concentration of $\mathrm{ssSO}_{4}{ }^{2}$ and $\mathrm{nssSO}_{4}{ }^{2}$ is most likely a result of sea spray and biogenic productivity from the nearby ocean. Additional sources of $\mathrm{nsSSO}_{4}{ }^{2-}$ may originate from dust, nearby volcanic emissions and local anthropogenic activity.

Empirical orthogonal function (EOF) analysis was conducted on the major soluble ion suite $\left(\mathrm{Na}^{+}, \mathrm{nssK} \mathrm{Cl}^{-}, \mathrm{Mg}^{2+}\right.$, $\mathrm{nssCa}^{2+}, \mathrm{nssK}^{+}$and $\left.\mathrm{nssSO}_{4}{ }^{2-}\right)$ to investigate common variability and inter-species relationships (Table 3). EOF1 accounts for $\sim 43 \%$ of the total variance in the soluble ions. $\mathrm{Na}^{+}, \mathrm{Cl}^{-}$and $\mathrm{Mg}^{2+}$ are strongly loaded on EOF1 ( 95\%), representing the influx of sea-water source ions. EOF2 represents $\sim 26 \%$ of the total variance and is strongly loaded positively by $\mathrm{nssK}^{+}(\sim 60 \%)$ and $\mathrm{nssCa}^{2+}(\sim 64 \%)$, indicating probable dust species. nssSO ${ }_{4}{ }^{2-}$ does not load strongly on EOF2 and, as suggested earlier by marine weight calculations, does not appear to have a strong crustal source. Instead, nssSO ${ }_{4}{ }^{2-}$ is primarily grouped with $\mathrm{NO}_{3}{ }^{-}$on EOF3, which represents $\sim 10 \%$ of total ion variance, at $32 \%$ and $67 \%$ respectively. Both $\mathrm{SO}_{4}{ }^{2-}$ and $\mathrm{NO}_{3}{ }^{-}$are known anthropogenic pollutants and their common variance may suggest that nearby anthropogenic activities are impacting snow chemistry. $\mathrm{MS}^{-}$, an atmospheric oxidation product of dimethyl sulfide originating from biogenic marine sources, is primarily (40\%) loaded on EOF4 ( $7 \%$ of total ion variance).

\section{Concentrations and statistical analysis of major and trace elements}

Statistical summaries of major and trace element concentrations are presented in Table 2. Based on concentrations, trace elements can be categorized into three groups: (1) high concentrations: $\mathrm{Na}$ represents $74.7 \%$ of total element

Table 3. EOF analysis of major soluble ions at Glaciar Marinelli

\begin{tabular}{lrrrr}
\hline & EOF1 & EOF2 & EOF3 & EOF4 \\
\hline Total \% & 43.14 & 25.62 & 13.47 & 8.80 \\
$\mathrm{Na}^{+}$ & 95.12 & 0.06 & -2.83 & -1.67 \\
$\mathrm{nsSK}^{+}$ & 9.88 & 59.91 & -0.52 & 5.37 \\
$\mathrm{Mg}^{2+}$ & 94.77 & 0.01 & -2.89 & -0.96 \\
$\mathrm{nsCa}^{2+}$ & 0.93 & 64.37 & -0.18 & 17.71 \\
$\mathrm{MS}^{-}$ & 11.07 & -42.89 & 0.08 & 40.41 \\
$\mathrm{Cl}^{-}$ & 94.99 & 0.03 & -2.69 & -1.85 \\
$\mathrm{NO}_{3}{ }^{-}$ & 4.84 & 19.35 & 66.69 & -1.46 \\
$\mathrm{nsSSO}_{4}{ }^{2-}$ & 33.52 & -18.37 & 31.91 & 0.93 \\
& & & & \\
\hline
\end{tabular}

concentrations; (2) intermediate concentrations: $\mathrm{Mg}, \mathrm{Al}, \mathrm{Ca}$ and Fe represent $10.1 \%, 6.5 \%, 6.1 \%$ and $2.4 \%$ respectively; (3) low concentrations: the remaining elements combined represent $0.2 \%$. $\mathrm{Na}$ and $\mathrm{Mg}$, as with the soluble ions, are assumed to completely originate from sea water. Ca showed the same nss and ss percentages as $\mathrm{Ca}^{2+}$. $\mathrm{Al}$ and $\mathrm{Fe}$ are assumed to reflect nss concentrations because of their minute concentrations in sea water.

Enrichment factors (EF) were calculated to provide compositional major and trace element comparisons between snow samples and average upper-crust values (Fig. 2.). $\mathrm{EF}_{\text {upper crust }}$ values were calculated using:

$$
\mathrm{EF}=\left[\frac{\left(\frac{X_{1}}{\operatorname{Ref}_{1}}\right)}{\left(\frac{X_{2}}{\operatorname{Ref}_{2}}\right)}\right],
$$

where EF is the enrichment factor of snow-sample to uppercrust values, $X_{1}$ is the concentration of element in the snow sample $\left(\mathrm{ng} \mathrm{L}^{-1}\right), X_{2}$ is the concentration of element in the upper crust $\left(\mathrm{ng} \mathrm{L}^{-1}\right), \operatorname{Ref}_{1}$ is the concentration of the reference element in the snow sample $\left(n \mathrm{LL}^{-1}\right)$ and $\operatorname{Ref}_{2}$ is the concentration of reference element in the upper crust (ng L ${ }^{-1}$ ).

$\mathrm{Al}, \mathrm{Fe}, \mathrm{Ba}$ and La were used as the reference elements to reduce any potential bias from one upper-crust element (Planchon and others, 2002; Barbante and others, 2003; Osterberg and others, 2008). The trace element concentrations for the average upper crust are from Wedepohl (1995). All reference elements produced similar EF values. The medians of reference element (Al, Fe, Ba and La) EF values are presented in Figure 2. Due to dust source areas that may have element concentrations greater than mean upper-crust values, researchers have suggested that

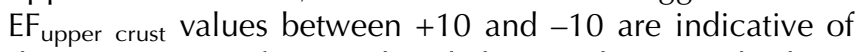
dominant inputs from rock/soil dust (Barbante and others, 2003). EF values $>10$ may suggest non-crustal, notably anthropogenic influences. The proximity of major sea-water sources must be considered when evaluating the trace element EF values. The majority of the trace elements display EF values very close to upper-crust values between 1 and 3. The high EF values for $\mathrm{Na}$ and $\mathrm{Mg}$ are assumed to be products of dominant sea-water contributions. Median EF values for $\mathrm{Cr}$ are slightly above 10 (18.34) and may suggest that anthropogenic pollutants are reaching the site. The greatest median $\mathrm{EF}$ values are very high and exhibited by $\mathrm{Bi}$ and $\mathrm{Cd}$ reporting values of 719.75 and 210.96 respectively. These high values are most likely attributable to nearby cities/towns (e.g. Punta Arenas), local logging or perhaps local marine transportation. Another potential source of the 
Table 4. EOF analysis of major and trace elements at Glaciar Marinelli

\begin{tabular}{lrrrr}
\hline & EOF1 & EOF2 & EOF3 & EOF4 \\
\hline Total \% & 52.51 & 16.20 & 14.91 & 5.66 \\
$\mathrm{Sr}$ & 35.67 & 47.30 & -12.01 & -0.01 \\
$\mathrm{Cd}$ & -0.17 & 8.58 & 45.69 & -7.62 \\
$\mathrm{Cs}$ & 85.89 & 0.15 & -0.43 & 0.87 \\
$\mathrm{Ba}$ & 82.92 & -0.54 & 0.07 & 5.13 \\
$\mathrm{La}$ & 6.50 & 21.28 & 69.03 & 0.00 \\
$\mathrm{Ce}$ & 19.84 & 14.87 & 49.78 & 2.11 \\
$\mathrm{Pr}$ & 16.30 & 17.76 & 63.10 & -0.01 \\
$\mathrm{Ho}$ & 86.13 & -8.24 & 0.04 & -3.31 \\
$\mathrm{Er}$ & 88.27 & -5.60 & 1.17 & -2.94 \\
$\mathrm{Bi}$ & 85.35 & -2.51 & 0.43 & 1.23 \\
$\mathrm{U}$ & 32.58 & 8.65 & -3.91 & 26.66 \\
$\mathrm{Al}$ & 81.85 & -11.25 & 0.18 & -1.87 \\
$\mathrm{Ca}$ & 29.60 & 36.27 & -10.44 & 2.08 \\
$\mathrm{Ti}$ & 80.41 & -5.95 & -0.57 & -1.55 \\
$\mathrm{~V}$ & 79.20 & -8.93 & -0.08 & -6.70 \\
$\mathrm{Cr}$ & 20.88 & -10.51 & 1.52 & 42.94 \\
$\mathrm{Mn}$ & 89.08 & -2.78 & -0.77 & -0.40 \\
$\mathrm{Fe}$ & 88.93 & -6.93 & 0.01 & -1.69 \\
$\mathrm{Na}$ & 19.31 & 57.42 & -16.14 & -2.73 \\
$\mathrm{Mg}$ & 21.31 & 48.44 & -22.71 & -3.38 \\
& & & & \\
\hline & & & &
\end{tabular}

enriched $\mathrm{Bi}$ and $\mathrm{Cd}$ may be local volcanism (i.e. degassing) (Rosman and others, 1998; Matsumoto and Hinkley, 2001; Vallelonga and others, 2004). High EF values of $\mathrm{Cd}$ and $\mathrm{Bi}$ (several hundred times crustal compositions) were reported by Mishra and others (2004) in an aerosol study at King Sejong Station on King George Island $(\sim 1000 \mathrm{~km}$ southeast of Glaciar Marinelli; Fig. 1) and attributed to local anthropogenic emissions and/or long-range transported anthropogenic pollutants. Several sites in Antarctica have also reported levels of heavy metal anthropogenic pollutants (Boutron and others, 1994; Planchon and others, 2002; Vallelonga and others, 2004).

EOF analysis was also conducted on the major and trace element suite to investigate common variability and interspecies relationships (Table 4 ). EOF1 accounts for $\sim 53 \%$ of the total variance in the trace elements and is heavily loaded with the elements $\mathrm{Fe}, \mathrm{Al}, \mathrm{Mn}, \mathrm{Cs}, \mathrm{Ba}, \mathrm{Bi}, \mathrm{V}, \mathrm{Ti}$ and the rareearth elements (REE) $\mathrm{Ho}$ and $\operatorname{Er}(79-89 \%)$. Based on the elemental composition and EF calculations, EOF1 appears to represent a dust source signal. Bi, previously mentioned as a potential anthropogenic species, may have transport pathways similar to those of the primary dust aerosol input. EOF2 represents $\sim 16 \%$ of the total variance and is strongly loaded by known sea-salt elements $\mathrm{Na}(\sim 57 \%)$, Mg ( 48\%) and $\mathrm{Sr}(47 \%)$ (Ikegawa and others, 1997). Ca is primarily divided between EOF2 ( 36\%) and EOF1 ( 30\%), suggesting that $\mathrm{Ca}$ inputs are from both marine and dust sources. EOF3 ( $\sim 15 \%$ of the total variance) is strongly loaded by REEs (La $(\sim 69 \%)$, Ce $(\sim 49 \%)$ and $\operatorname{Pr}(\sim 63 \%))$, which are expected to derive from a crustal source and may represent a secondary dust input. $\mathrm{Cd}$ is also strongly loaded on EOF3, but it is biased by one particular $\mathrm{Cd}$ concentration that is an order of magnitude above the median $\mathrm{Cd}$ value and therefore may possibly represent contamination rather than an anthropogenic source. EOF4 represents $\sim 6 \%$ of the total variance and is loaded by $\mathrm{Cr}(\sim 43 \%)$ and could potentially be a crustal input or anthropogenic as EF values suggest.

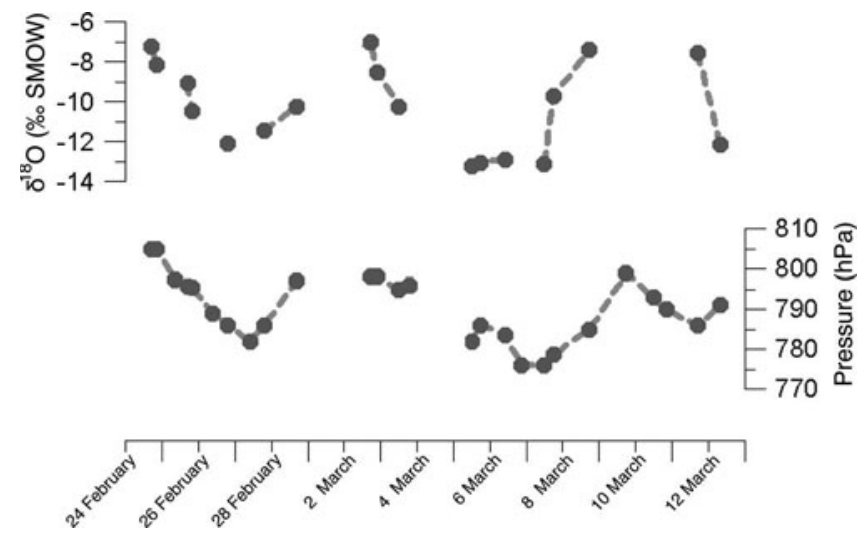

Fig. 3. Temporal trends of $\delta^{18} \mathrm{O}$ and pressure at Glaciar Marinelli. Discontinuities in trend lines indicate days with no collected samples.

Given the limited time period of the fresh-snow surface study, it is not possible to assess seasonal variations of trace elements at Glaciar Marinelli. However, an atmospheric aerosol study reported by Mishra and others (2004) at King Sejong Station, subject to regional atmospheric circulation similar to that at the Cordillera Darwin, may offer a comparable example of relative summer concentrations of trace elements, as well as possibly suggest the seasonality of trace elements that might be exhibited at Glaciar Marinelli. Of the similar trace elements analyzed, it was observed that on $\mathrm{KGl}, \mathrm{Bi}, \mathrm{Cd}$ and $\mathrm{Cs}$ displayed maximum concentrations during the summer. These high levels of $\mathrm{Bi}$ and $\mathrm{Cd}$, previously mentioned as potential anthropogenic species, correspond to increased human activity during the summer season on KGl. However, as reported by Iriondo (2000) and Mishra and others (2004), summer winds are predominately from the northwest and may transport crustal and anthropogenic elements from South America. $\mathrm{Al}, \mathrm{Ba}, \mathrm{Cr}$ and $\mathrm{V}$ showed maximum concentrations during the autumn, and $\mathrm{Sr}$ peaked in the spring. Although, the Cordillera Darwin and KGI share similar regional meteorology, marked differences may be present in the seasonal variations of trace elements as a result of Glaciar Marinelli's proximity to larger crustal (ice-free land) and anthropogenic sources, particle scavenging during transport, and the presence of sea ice.

\section{$\delta^{18} \mathrm{O}$, barometric pressure and air-mass trajectories}

$\delta^{18} \mathrm{O}$ and on-site barometric pressure are presented in Figure 3. Time series are not continuous. On 1 and 4 March, samples were not collected. $\delta^{18} \mathrm{O}$ values (statistical summary in Table 2) vary steadily over the 17 day period, with three peaks in less depleted $\delta^{18} \mathrm{O}$ values and three troughs in more depleted $\delta^{18} \mathrm{O}$ values. Examination of these $\delta^{18} \mathrm{O}$ trends in relation to recorded on-site observations of barometric pressure suggests a possible connection. The linear correlation coefficient between $\delta^{18} \mathrm{O}$ and pressure is $0.60(p<0.007, n=18)$. Stable-isotope ratios are controlled by air temperature, amount of precipitation (amount effect) and the air-mass transport from source regions. In terms of pressure, which can indicate storm conditions (i.e. intensity), the positive correlation with $\delta^{18} \mathrm{O}$ may suggest that stronger storm conditions/lower pressure coincided with greater precipitation, resulting in more depleted values of $\delta^{18} \mathrm{O}$ (amount effect). On-site air-temperature observations revealed no relationship with $\delta^{18} \mathrm{O}(r=0.06)$, and on-site precipitation measurements were not conducted. 


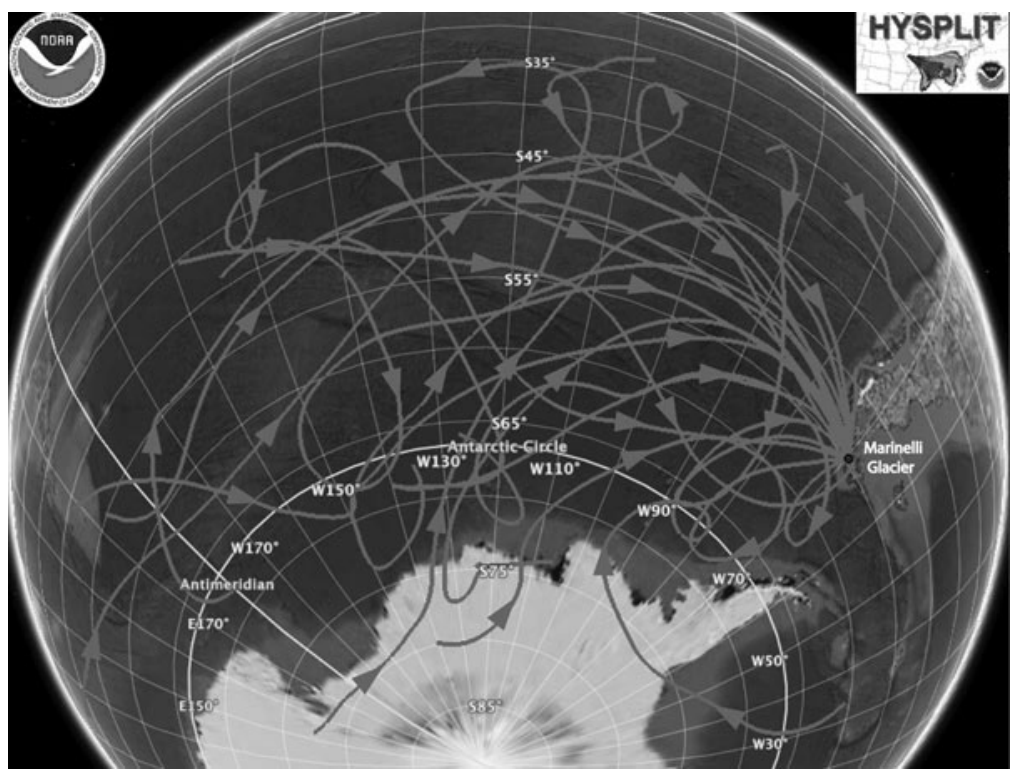

Fig. 4. Hysplit 7 day backward trajectories (24 February-12 March 2006) impacting the sampling site (Google Earth image).

Seven-day Hysplit backward trajectory analysis (NOAA, http://www.arl.noaa.gov/ready/open/hysplit4.html) indicated that air-mass movements during the snow sample campaign (24 February-12 March 2006) were primarily from the northwest, but also from the southwest and west, suggesting that the moisture source and majority of chemistry species originated from the Pacific Ocean and the Drake Passage (Fig. 4). The trajectories ranged from $\sim 30^{\circ} \mathrm{S}$ to $\sim 80^{\circ} \mathrm{S}$, reaching regions such as Antarctica, the Weddell Sea and New Zealand. Based on the air-mass trajectories and far distances to land masses, dust and anthropogenic species are probably local, but long-range transport of dust and pollution from arid and industrial sources (e.g. Australia) cannot be excluded.

\section{Regional major-ion records}

To make additional interpretations of the snow chemistry data from Glaciar Marinelli, major-ion concentrations are compared to results reported at nearby sites, ranging from northern sites (e.g. Cerro Tapado $\left(\sim 30^{\circ} \mathrm{S}, 69^{\circ} \mathrm{W}\right.$; $5536 \mathrm{ma.s.I.})$ ) in the central Andes to southern sites on $\mathrm{KGl}\left(62^{\circ} 07^{\prime} \mathrm{S}, 58^{\circ} 37^{\prime} \mathrm{W}\right.$; 575-690 ma.s.l.; Fig. 1$)$. It is important to recognize that seasonal variations of chemistry at Glaciar Marinelli are not established, so comparisons are preliminary. Glaciar Marinelli mean surface snow concentrations and available annual mean concentrations from snow-pit and ice-core datasets are presented in Table 5. Based on marine weight calculations at most of the sites, $\mathrm{Na}^{+}$and $\mathrm{Cl}^{-}$concentrations are primarily sourced from sea water. The calculation was not conducted for Monte San Valentín (MSV) and Tyndall glaciers because annual mean concentrations have not been published; however, $\mathrm{Na}^{+}$and $\mathrm{Cl}^{-}$concentrations were presumed to be dominantly from marine sources (Shiraiwa and others, 2002; Vimeux and others, 2008). At Mercedario, $\mathrm{Na}^{+}$concentrations are higher than $\mathrm{Cl}^{-}$, yielding a $\mathrm{Cl}^{-}: \mathrm{Na}^{+}$ratio of 0.82 , significantly lower than the average sea-water ratio of 1.16 and suggesting an additional input of $\mathrm{Na}^{+}$from a nss source. The contribution of ss versus nss ions is used in this study to classify sites as either marine- or crustal-source dominated. The more southerly sites (Glaciar Marinelli, Gorra Blanca Norte (GBN) and Glaciar Perito Moreno (GPM)) are dominated by marine inputs ( $\mathrm{ssNa}^{+}$and $\mathrm{ssCl}^{-}$), while the more northerly sites (Mercedario, Plomo and Tapado) are more

Table 5. Annual mean major soluble ion concentrations $\left(\mu \mathrm{EqL}^{-1}\right)$

\begin{tabular}{|c|c|c|c|c|c|c|c|c|c|c|c|}
\hline Site & Source & $\begin{array}{c}\text { Elevation } \\
\text { ma.s.I }\end{array}$ & $\mathrm{Na}^{+}$ & $\mathrm{K}^{+}$ & $\mathrm{Mg}^{2+}$ & $\mathrm{Ca}^{2+}$ & $\mathrm{Cl}^{-}$ & $\mathrm{NO}_{3}{ }^{-}$ & $\mathrm{SO}_{4}{ }^{2-}$ & $\mathrm{nsSSO}_{4}{ }^{2-}$ & $\mathrm{nssCa}^{2+}$ \\
\hline Glaciar Marinelli ${ }^{*}$ & This study & 1823 & 8.15 & 0.50 & 1.72 & 0.71 & 9.60 & 0.30 & 2.03 & 1.01 & 0.35 \\
\hline Gorra Blanca Norte & Schwikowski and others (2006) & 2300 & 2.72 & & 0.5 & 0.84 & 2.65 & 0.44 & & 0.56 & 0.72 \\
\hline Glaciar Perito Moreno & Aristarain and Delmas (1993) & $\sim 2000$ & 4.3 & & & & 4.85 & 0.32 & & & \\
\hline Monte San Valentín & Vimeux and others (2008) & 3747 & & & & & & & & & 0.28 \\
\hline Mercedario & Bolius and others (2006) & 6070 & 2.36 & 0.16 & 0.9 & 3.96 & 1.25 & 2.82 & 5.14 & 4.55 & 3.87 \\
\hline Plomo & Bolius and others (2006) & 5300 & 1.54 & 0.14 & 1.86 & 11.24 & 2.15 & 4.53 & 17.28 & 16.89 & 11.18 \\
\hline Tapado & Bolius and others (2006) & 5536 & 1.6 & 0.37 & 0.68 & 9.76 & 1.9 & 3.11 & 8.55 & 8.15 & 9.70 \\
\hline Lange & Simões and others (2004) & 690 & & & & & 120.4 & $<0.21$ & 27.66 & 15.26 & \\
\hline Drake & Simões and others (2004) & 600 & & & & & 857.55 & 19.84 & 118 & 29.67 & \\
\hline Ezcurra & Simões and others (2004) & 575 & & & & & 589.27 & 24.44 & 48.54 & -12.1 & \\
\hline
\end{tabular}

*Values represent 17 days of fresh snow. 
influenced by crustal inputs ( $\mathrm{nssCa}^{2+}$ and $\mathrm{nssSO}_{4}{ }^{2-}$ ). This is not surprising since the northern sites are further inland and located in arid regions where dust sources are more abundant. $\mathrm{Ca}^{2+}$ and $\mathrm{SO}_{4}{ }^{2-}$ are the two most abundant ions at Mercedario, Plomo and Tapado. Marine weight calculations suggest nssCa represents $>98 \%$ of the $\mathrm{Ca}^{2+}$, and nssSO ${ }_{4}{ }^{2-}>97 \%$ of the $\mathrm{SO}_{4}{ }^{2-}$, at these sites. The high values of $\mathrm{SO}_{4}{ }^{2-}$ were also suggested to be from a local anthropogenic emission source (e.g. Santiago) (Bolius and others, 2006). Seasonality at Mercedario shows clear increases in all major ions during the summer. The enrichment of summer chemistry was attributed to the intensity of vertical mixing in the atmosphere, and sublimation at the site.

The near-coastal location and distance from major dustsource regions of the southern (South American) sites explain the dominant marine influence and are reflected by high concentrations of $\mathrm{Na}^{+}$and $\mathrm{Cl}^{-}$relative to predominately crustal ions (e.g. $\left.\mathrm{Ca}^{2+}\right)$. The differences in mean $\mathrm{Na}^{+}$and $\mathrm{Cl}^{-}$concentrations between the southern South American sites may be due to a combination of elevation, distance from the Pacific Ocean and air-mass trajectories. MSV, located at the highest elevation (3747 m), displays the lowest $\mathrm{Na}^{+}$concentration, $\sim 0.2-1.0 \mu \mathrm{Eq} \mathrm{L}^{-1}$ (estimated from $1989 \mathrm{Na}^{+}$depth/age graph; Vimeux and others, 2008). The southern site's $\mathrm{Na}^{+}$and $\mathrm{Cl}^{-}$concentrations appear inversely related to elevation. Glaciar Tyndall, located at the lowest elevation $(1756 \mathrm{~m})$, has the highest concentrations of $\mathrm{Na}^{+}$and $\mathrm{Cl}^{-}$. Shiraiwa and others (2002) state that the major ions $\left(\mathrm{Na}^{+}, \mathrm{Cl}^{-}\right.$and $\left.\mathrm{NO}_{3}{ }^{-}\right)$at Glaciar Tyndall are an order of magnitude higher than those reported by Aristarain and Delmas (1993), but the rapid decrease in ions over the top $4 \mathrm{~m}$ by meltwater elution precludes the estimate of annual concentrations. The reason mean $\mathrm{Na}^{+}$and $\mathrm{Cl}^{-}$concentrations are higher at Glaciar Marinelli than at other Patagonian sites (except Glaciar Tyndall) may not be elevation or marine source distance, but particular atmospheric conditions during the 17 day field campaign. GBN, a nearby site that shares similar regional atmospheric circulation, displays large peaks in summer concentrations of ss species $\left(\mathrm{Na}^{+}, \mathrm{Cl}^{-}\right.$and $\left.\mathrm{Mg}^{2+}\right)$. The increases in ss concentrations were attributed to the high summer wind speeds that promote sea-spray formation. Extrapolation of this seasonal signal to Glaciar Marinelli would suggest that above-annual-mean ss concentrations were more likely deposited. Further south, the KGl sites display extremely high annual concentration means of $\mathrm{Cl}^{-}$and $\mathrm{SO}_{4}{ }^{2-}$ compared with the South American sites. The high values of marine species can be attributed to the low elevation of the sites and close proximity to sea water. $\mathrm{nsSSO}_{4}{ }^{2-}$ concentrations on $\mathrm{KGl}$ are attributed mainly to biogenic dimethyl sulfate (DMS) and possibly volcanic sources (Simões and others, 2004).

Comparisons between $\mathrm{NO}_{3}{ }^{-}$concentrations show marked differences between northern and southern sites of South America. Mean $\mathrm{NO}_{3}{ }^{-}$concentrations are an order of magnitude greater at northern than at southern sites, most likely due to more abundant dust source locations. In addition, Bolius and others (2006) suggested that high $\mathrm{NO}_{3}{ }^{-}$ levels at Mercedario and Cerro Tapado may be due to local anthropogenic emission sources from cities such as Santiago, Chile. The southern sites, GBN and GPM, are reported to have lower $\mathrm{NO}_{3}{ }^{-}$concentrations than pre-industrial medians from a core from the European Alps (Schwikowski and others, 1999). The low $\mathrm{NO}_{3}{ }^{-}$concentrations present at
Glaciar Marinelli are similar to Schwikowski and others (1999) and also reflect the low anthropogenic emissions in southern South American regions (e.g. Patagonia and Tierra del Fuego). Although, annual mean $\mathrm{NO}_{3}{ }^{-}$values are not available, a depth/time graph revealed similarly low concentrations at MSV (Vimeux and others, 2008). Because pre-industrial $\mathrm{NO}_{3}{ }^{-}$concentrations have not been assessed in the region and $\mathrm{NO}_{3}{ }^{-}$contribution from dust sources is unclear, it is difficult to evaluate anthropogenic impacts via concentration levels alone. However, previously mentioned EF calculations of Glaciar Marinelli chemistry suggest possible anthropogenic influences. KGI sites show varying $\mathrm{NO}_{3}{ }^{-}$concentrations, with low levels (below detection limit) at the flat ice divide of Lange Glacier $\left(62^{\circ} 07^{\prime} \mathrm{S}\right.$, $58^{\circ} 37^{\prime}$ W; 690 ma.s.I.), similar to southern South American sites, but, very high $\mathrm{NO}_{3}{ }^{-}$concentrations at the lowerelevation and more near-coastal sites (Drake and Ezurra glaciers) (Table 3). The higher concentrations may be explained by local rock sources, local emission from research stations, or perhaps post-depositional processes (e.g. superficial melting, percolation and refreezing) which can alter ion content. KGl summer temperatures at sea level are frequently above $0^{\circ} \mathrm{C}$ (Ferron and others, 2004). Majorion concentrations from Lange Glacier were considered unaltered (top $2.7 \mathrm{~m}$ ) and representative of the original precipitation, thereby providing background chemical compositions (Simões and others, 2004).

\section{SUMMARY}

This is the first report on fresh-snow chemistry (stable isotopes, major ions and trace elements) from Glaciar Marinelli. Data interpretations suggest that snow chemistry is dominantly loaded by marine species $\left(\mathrm{Cl}^{-}, \mathrm{Na}^{+}\right.$and $\mathrm{SsSO}_{4}{ }^{2-}$ ). $\mathrm{Na}^{+}$and $\mathrm{Cl}^{-}$account for $\sim 70 \%$ of the total ion load, and $\mathrm{Na}$ accounts for $\sim 75 \%$ of total element loading. Contributions of crustal chemistry appear to be very low; estimated nssCa only represents $\sim 1 \%$ of the total ion load, and nssCa, Al, and Fe represent approximately 6\%, 6\% and $2 \%$ of the total trace element load respectively. EOF analysis may suggest two possible dust sources, one primarily represented by $\mathrm{Al}$ and Fe and another by $\operatorname{REE}(\mathrm{La}, \mathrm{Ce}, \mathrm{Pr})$. $\mathrm{EF}$ calculations of trace elements suggest the majority of elements are within average upper-crustal ratios. Cr shows moderate median enrichment values at $\sim 20$, but major median enrichments of $\mathrm{Bi}$ and $\mathrm{Cd}$ (hundreds of times) suggest possible anthropogenic sources. Anthropogenic inputs are also suggested by EOF ion grouping of $\mathrm{nsSO}_{4}{ }^{2-}$ with $\mathrm{NO}_{3}{ }^{-}$. Pollutant sources may originate from local cities/ towns (e.g. Punta Arenas), logging activities and marine traffic. The linear relationship between $\delta^{18} \mathrm{O}$ and on-site barometric pressure $(r=0.60, p<0.007, n=18)$ may suggest that stronger storm conditions coincided with greater precipitation (amount effect), resulting in more depleted values of $\delta^{18} \mathrm{O}$. During the sampling period, back-trajectory analysis shows air masses coming primarily from the west and southwest. The dominance of marine species and concentrations of $\mathrm{NO}_{3}{ }^{-}$are similar to the findings of previous studies in Patagonia. Additional temporal and spatial glaciochemical sampling of Glaciar Marinelli is necessary to determine seasonal variations of snow chemistry. This study, however, provides a preliminary assessment of snow chemistry from the southernmost glaciated region outside Antarctica. 


\section{ACKNOWLEDGEMENTS}

This research was funded by US National Oceanic and Atmospheric Administration grant NOAA NA06OAR4310206. We especially thank Centro de Estudios Científicos researchers J. Wendt and A. Wendt for logistical help, and DAP for helicopter support.

\section{REFERENCES}

Aristarain, A.J. and R.J. Delmas. 1993. Firn-core study from the southern Patagonia ice cap, South America. J. Glaciol., 39(132), 249-254.

Barbante, C. and 7 others. 2003. Seasonal variations of heavy metals in central Greenland snow deposited from 1991 to 1995. J. Environ. Monitor., 5(2), 328-335.

Bolius, D., M. Schwikowski, T. Jenk, H.W. Gäggeler, G. Casassa and A. Rivera. 2006. A first shallow firn-core record from Glaciar La Ollada, Cerro Mercedario, central Argentine Andes. Ann. Glaciol., 43, 14-22.

Boutron, C.F., J.P. Candelone and S.M. Hong. 1994. Past and recent changes in the large-scale tropospheric cycles of lead and other heavy metals as documented in Antarctic and Greenland snow and ice: a review. Geochim. Cosmochim. Acta, 58(15), 3217-3225.

Ferron, F.A., J.C. Simões, F.E. Aquino and A.W. Setzer. 2004. Air temperature time series for King George Island, Antarctica. Pesqui. Antárt. Brasil., 4, 155-169.

Field, M.P. and R.M. Sherrell. 2003. Direct determination of ultratrace levels of metals in fresh water using desolvating micronebulization and HR-ICP-MS: application to Lake Superior waters. J. Anal. Atom. Spectrom., 18(3), 254-259.

Gabrielli, P. and 8 others. 2006. Direct determination of rare earth elements at the subpicogram per gram level in Antarctic ice by ICP-SFMS using a desolvation system. Anal. Chem., 78(6), 1883-1889.

Holland, H.D. 1978. The chemistry of the atmosphere and oceans. New York, Wiley Interscience.

Holmlund, P. and H. Fuenzalida. 1995. Anomalous glacier responses to 20th century climatic changes in Darwin Cordillera, southern Chile. J. Glaciol., 41(139), 465-473.

Ikegawa, M., M. Kimuva, K. Honda, K. Makita, Y. Fujii and Y. Itokawa. 1997. Springtime peaks of trace metals in Antarctic snow. Eviron. Health Perspect., 105(6), 654-659.

Iriondo, M. 2000. Patagonia dust in Antarctica. Quat. Int., 68-71, 83-86.

Kalnay, E. and 21 others. 1996. The NCEP/NCAR 40-year reanalysis project. Bull. Am. Meteorol. Soc., 77(3), 437-471.

Legrand, M. and P. Mayewski. 1997. Glaciochemistry of polar ice cores: a review. Rev. Geophys., 35(3), 219-243.

Matsumoto, A. and T.K. Hinkley. 2001. Trace metal suites in Antarctic pre-industrial ice are consistent with emissions from quiescent degassing of volcanoes worldwide. Earth Planet. Sci. Lett., 186(1), 33-43.
Mayewski, P.A., W.B. Lyons and N. Ahmad. 1983. Chemical composition of a high altitude fresh snowfall in the Ladakh Himalayas. Geophys. Res. Lett., 10(1), 105-108.

Mayewski, P.A., W.B. Lyons, N. Ahmad, G. Smith and M. Pourchet. 1984. Interpretation of the chemical and physical time-series retrieved from Sentik Glacier, Ladakh Himalaya, India. J. Glaciol., 30(104), 66-76.

Miller, A. 1976. The climate of Chile. In Schwerdtfeger, W., ed. Climates of Central and South America. New York, Elsevier, 113-145. (World Survey of Climatology 12.)

Mishra, V.K., K.-H. Kim, S. Hong and K. Lee. 2004. Aerosol composition and its sources at the King Sejong Station, Antarctic peninsula. Atmos. Environ., 38(24), 4069-4084.

Osterberg, E.C., M.J. Handley, S.B. Sneed, P.A. Mayewski and K.J. Kreutz. 2006. Continuous ice core melter system with discrete sampling for major ion, trace element, and stable isotope analyses. Environ. Sci. Technol., 40(10), 3355-3361.

Osterberg, E. and 10 others. 2008. Ice core record of rising lead pollution in the North Pacific atmosphere. Geophys. Res. Lett., 35(5), L05810. (10.1029/2007GL032680.)

Planchon, F.A.M. and 7 others. 2002. Changes in heavy metals in Antarctic snow from Coats Land since the mid-19th to the late20th century. Earth Planet. Sci. Lett., 200(1-2), 207-222.

Rosman, K..J.R. and 6 others. 1998. Lead isotopes and selected metals in ice from Law Dome, Antarctica. Ann. Glaciol., 27, 349-354.

Schwikowski, M., A. Döscher, H. Gäggeler and U. Schotterer. 1999. Anthropogenic versus natural sources of atmospheric sulphate from an Alpine ice core. Tellus, 51B(5), 938-951.

Schwikowski, M., S. Brütsch, G. Casassa and A. Rivera. 2006. A potential high-elevation ice-core site at the Hielo Patagónico Sur. Ann. Glaciol., 43, 8-13.

Shaw, G.E. 1988. Antarctic aerosols: a review. Rev. Geophys., 26(1), 89-112.

Shiraiwa, T. and 6 others. 2002. High net accumulation rates at Campo de Hielo Patagónico Sur, South America, revealed by analysis of a $45.97 \mathrm{~m}$ long ice core. Ann. Glaciol., 35, 84-90.

Simões, J.C. and 6 others. 2004. Ice core study from the King George Island, South Shetlands, Antarctica. Pesqui. Antárt. Brasil., 4, 9-23.

Vallelonga, P. and 8 others. 2004. Elemental indicators of natural and anthropogenic aerosol inputs to Law Dome, Antarctica. Ann. Glaciol., 39, 169-174.

Vimeux, F. and 7 others. 2008. A promising location in Patagonia for paleoclimate and paleoenvironmental reconstructions revealed by a shallow firn core from Monte San Valentín (Northern Patagonia Icefield, Chile). J. Geophys. Res., 113(D16), D16118. (10.1029/2007JD009502.)

Wedepohl, K.H. 1995. The composition of the continental crust. Geochim. Cosmochim. Acta, 59(7), 1217-1232.

Yamada, T. 1987. Glaciological characteristics revealed by 37.6-m deep core drilled at the accumulation area of San Rafael Glacier, the Northern Patagonia Icefield. Bull. Glacier Res., 4, 59-67. 